\title{
School Psychologists and School Reform: Challenges and Opportunities
}

\author{
Anton Furman ${ }^{1}$ \\ Department oi Psychology, Faculty of Education \\ - Mate) Bel Universit - Slovakia
}

\begin{abstract}
Resumo
School Psychology is a system of psychological services for schools and a distinctive discipline within psychological sciences. Slovak and Czech Republics educational context are used in order to understand school Psychology within a system of education. Change of the political and economic system present reflections in the status of the school ofthe preparation of school psychologists in order to solve educational needs and problems.
\end{abstract}

Palavras chaves: School Psychology, school psychologist, school reform.

\section{Psicólogos Escolares e Reforma Educacional: Mudanças e Oportunidades}

\begin{abstract}
Summary
Psicologia escolar é um sistema de serviços psicológicos para escolas e uma disciplina distinta dentro da ciência psicológica. O contexto educacional da Eslováquia e da Chechênia são usados para se compreender a Psicologia Escolar dentro de um sistema educacional. Mudanças no sistema político e econômico atuais refletem-se no status da Psicologia Escolar e no preparo de psicólogos escolares para a solução das necessidades e problemas educacionais.
\end{abstract}

Key words: Psicologia Escolar, psicólogo escolar, reforma educacional.

\section{System of Education - Framework for School Psychology}

Since the beginning of the 20th century, where we usually can find the roots of school psychology, but since the end of World War II in particular, school psychology has developed into both a system of psychological services for schools (children, teachers, parents, administration) and a distinctive discipline within psychological sciences. The range of psychological services provided by school psychologist is very broad (see some intentional survey, e.g. Oakland, Cunnigham, 1992, Hu, Oakland, 1991, Marsh, 1991, EFPP A, 1997). One of the reasons is that school psychology functions within a system of education - and this is different from country to country. To understand school psychology in a particular country requires therefore understanding of its conceptual framework. In developing my thoughts about school psychology, I will use the Slovak and Czech Republics educational context as a framework. First of all, because I am most familiar with it but also because it is a quite good model, an example of the transformation and change which has become quite common around the world. Let me therefore brief1y describe the system of education in Slovakia (which can be extended to the Czech Republic in most ways).

\footnotetext{
${ }^{1}$ Endereço: 58 Plymouth Dr.. Apt. 1 B Norwood. MA CEP: 02062. USA -Anton- furman@yahoo.com
} 


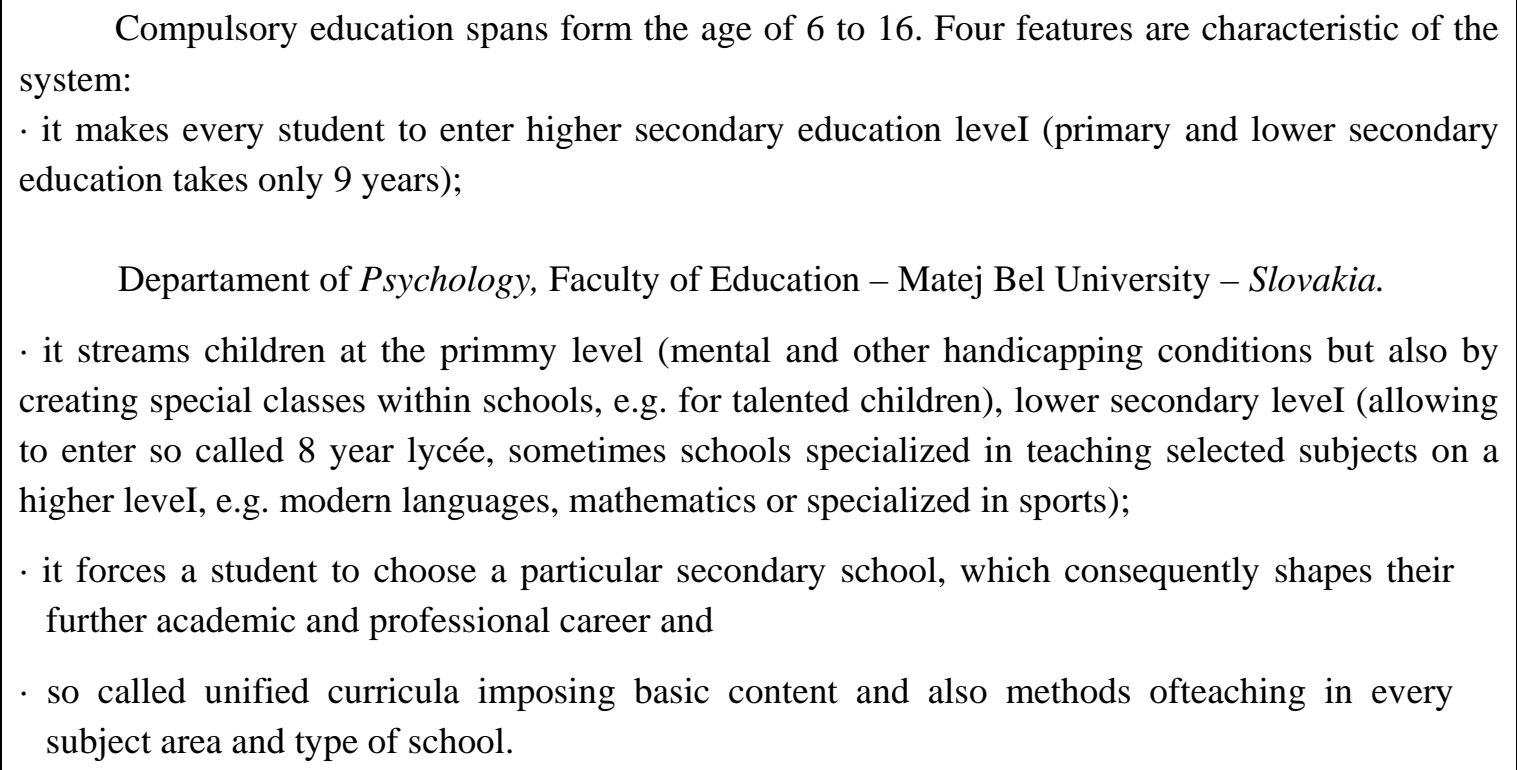

Compulsory education spans form the age of 6 to 16. Four features are characteristic of the system:

- it makes every student to enter higher secondary education leveI (primary and lower secondary education takes only 9 years);

Departament of Psychology, Faculty of Education - Matej Bel University - Slovakia.

- it streams children at the primmy level (mental and other handicapping conditions but also by creating special classes within schools, e.g. for talented children), lower secondary leveI (allowing to enter so called 8 year lycée, sometimes schools specialized in teaching selected subjects on a higher leveI, e.g. modern languages, mathematics or specialized in sports);

- it forces a student to choose a particular secondary school, which consequently shapes their further academic and professional career and

- so called unified curricula imposing basic content and also methods ofteaching in every subject area and type of school.

Figura 1. Organizational Chart of the School System in Slovakia

Both school system in Slovakia and the Czech Republic are known for their effectiveness in providing basic education to majority of the student population. Both countess score within the top tem in the international survey assessing students' achievement in mathematics, science, and reading (see e.g. Keys et al., 1997). What kinds of services are in demand in an educational framework similar to the described one?

It is clear that such system calls for a lot of diagnostic work to be done by specialists as well as a lot counseling provided to students, their parents, teachers, and school administration. When the system changes, it may require different set of services including those provided by school psychologists. Of course, the change in some core areas may be much slower than the others. For instance, there will be always expected that a school psychologist is able to work with individual children, to provide diagnostic insights, interventions, which other professionals can not offer. The priorities may, however, change and such changes should be reflected in competencies and therefore also preparation of school psychologists. Let us see what psychological service really has developed within the given framework in Slovakia and the Czech Republic. 
School Psychology in Slovakia (and the Czech Republic)

\begin{tabular}{|c|c|c|}
\hline Time & Slovak Republic & Czech Republic \\
\hline $\begin{array}{l}\text { Early 50- } \\
\text { ties }\end{array}$ & $\begin{array}{l}\text { - psychology - "ideological enemy" not welcome in } \\
\text { schools }\end{array}$ & \\
\hline $\begin{array}{l}\text { Late } 50- \\
\text { ties }\end{array}$ & $\begin{array}{l}\text { Psychological clinics started in major cities (Bratislava, } \\
\text { Kosice) }\end{array}$ & \\
\hline $\begin{array}{l}\text { Mid-late } \\
60 \text {-ties }\end{array}$ & $\begin{array}{l}\text { Courses for school psychologists (in Bratislava only). } \\
\text { (SP concepts: a school psvchologist "1/2" teacher, } \\
\text { "1/2" psychologist) }\end{array}$ & \\
\hline $\begin{array}{l}\text { Late } 60- \\
\text { ties }\end{array}$ & $\begin{array}{l}\text { Experimental use of psychologists based at the } \\
\text { psychological clinics in school }\end{array}$ & \\
\hline 1968 & \multicolumn{2}{|c|}{ "Prague Spring" } \\
\hline $\begin{array}{l}\text { Early } 70 \text {-ties } \\
\quad 1970\end{array}$ & \multicolumn{2}{|c|}{$\begin{array}{l}\text { Repression following the occupation } 01 \text { Czechoslovakia by the Soviet troops } \\
\text { The Slovak Psychological Society - a proposal to } \\
\text { Create post for school psychologists in } \\
\text { Secondary schools. }\end{array}$} \\
\hline 70.ties & $\begin{array}{l}\text { Discussion if school psychologists should be trained to } \\
\text { do both teaching and Psychological work or kept within } \\
\text { the framework of a "pure" psychology continues and } \\
\text { contributes to the failure of legalizing the profession of } \\
\text { school psychologists in Slovakia. } \\
\text { - Psychological Clinics are renamed to Pedagogical- } \\
\text { Psychological Guidance Centers. }\end{array}$ & $\begin{array}{c}\text { (the idea of school psychology was not develop } \\
\text { the Czech psychologists at this time) }\end{array}$ \\
\hline $\begin{array}{l}\text { 70-ties and } \\
80 \text {-ties }\end{array}$ & \multicolumn{2}{|c|}{$\begin{array}{l}\text { Pedagogical-Psychological Guidance Centers have been established in all district towns in } \\
\text { Czechoslovakia }\end{array}$} \\
\hline 1986 & \multicolumn{2}{|c|}{$\begin{array}{l}\text { "Foundations of School Psychology" bv J. Hvozdlk - first textbook on school psychology in the Central } \\
\text { Europe }\end{array}$} \\
\hline Mid 80-ties & \multicolumn{2}{|c|}{$\begin{array}{l}\text { New courses in Bratislava - prospective school psychologists studying lor } 5 \text { years psychology }+ \\
\text { pedagogy (without teacher qualification) or } 4 \text { years specializing in school, counseling and educational } \\
\text { psychology. }\end{array}$} \\
\hline $\begin{array}{l}\text { Late } 80 \text {-ties } \\
\text { June } 1989\end{array}$ & \multicolumn{2}{|c|}{$\begin{array}{l}\text { New attempts to introduce school psychologists in SK. Slovak Min. of Education bound to introduce } \\
\text { school psychologist to schools with } 500+\text { students (never came into life - the change in 1989) }\end{array}$} \\
\hline 1989 & \multicolumn{2}{|c|}{ Velvet Revolution } \\
\hline
\end{tabular}

Figura 2. Overview of the history of school psychology in Slovakia and the Czech Republic

The ideologists of the socialist governments (1948 - 1989) paid dose attention to schools and psychology - once considered as an ideological enemy (in the 50ties) -was not very welcome within the educational sector. Yet, in the 60-ties building of Psychological Clinics, later renamed to Pedagogical-Psychological Guidance Centers were started. These centers which can be found in all district towns (according the old system) today (totally about 50) have been providing variety of psychological and special education services, including psychological diagnosing, testing, counseling, some therapy and prevention programs. Explicit use of psychology was placed outside of schools. The consequences are that the use of psychological services by schools had to become more formal, amplifying the need for testing. Diagnosis based on use of standardized instruments and a written report was seen as necessity for backing any recommendations regarding students 
given by psychologists to the teachers or boards deciding about student placement. Besides Pedagogical-Psychological Guidance Centers many psychologists were employed by special schools and some secondary vocation schools that had a special status and could employ other specialists than teachers. Their work was sometimes more formal but it usually also included a lot of individual casework and interventions.

Although psychologists provided their services from outside and from within schools, school psychology was not recognized officially, in spite of several attempts by leading Slovak psychologists (Jurco, Duric, Hvozdik -just to name but a few). Psychological services were used by the state and school administration as they needed, including the times of reforms when it was necessary to evaluate the newly introduced measures (e.g. school reform in 1976). This phenomenon acts on even more general level than the system of education- it is the political system which influences the system of education. In his book... develops the line of arguments proving that the society uses its system of education to reproduce its existing power structure and classes. Theoretically it should be possible to influence changes in society by introducing systematic chances in education. And certainly, we see that schools are expected to challenge all variety of societal problems on daily basis. Teachers often feel overwhelmed by the problems, which they view as not related to their specialty. Particulariy subject specialists at the lower and higher secondary level expects that they do "only teaching". The rest is somebody else's job. School psychologists come at hand. Again, it may be a good feeling to be in demand. "Throwing the ball" to the "other side" is; however, not the best way achieve cooperation and synergy we are looking for. School psychologists may well become scapegoats for not being able to manage problems rooted on a different level of the system.

\section{Change of the Political and Economical System - RefIections in School Psychology}

The change of the political and economic system in 1989 opened the door to new oppol1unities. In June 1990 the School Psychology Association of the Czech and Slovak Federal Republics was established. Thanks to the professional contacts the Association was closely connected and cooperating with the International School Psychology Association. The Association adopted Constitution and Code of Ethics reflecting documents of this nature adopted by the ISP A. Enthusiasm of the first Executive Committee of the School Psychology Association of the CSFR allowed for a first newsletter to be published for the members of the Association. The newsletter has been having growing professional level, which resulted into transforming it a professional journal with registered ISSN number. Authors from the Slovak and Czech Republic as well as internationally recognized school psychologists publish their contributions in this journal. We hope the journal will reach also the teachers. They are targeted as a group, which should be, paid a lot of attention. It is via teachers' support that school psychology can achieve its mission and goals especially in a small country where the absolute number of school psychologists is not big enough to create pressure on authorities to adopt regulations supporting development of psychological services for schools. Ft is clear that with a political system, which allows more freedom, variability, individuality, there is more need for additional services. They are needed to substitute the directive or more prescriptive approaches. Co-operation between specialists involved in education becomes 
much more necessary than before. While it was possible to force formal co-operation before 1989 in Czechoslovakia; it was not possible after the "Velvet Revolution" anymore. The problem of communication and cooperation between school psychologists and teachers became more evident.

School Psychology in Slovakia (and the Czech Republic)

\begin{tabular}{|c|c|c|}
\hline Time & Slovak Republic & Czech Republic \\
\hline 1990 & \multicolumn{2}{|c|}{ School Psychology Association of the Czech and Slovak Federal Republic established } \\
\hline Early 90.ties & $\begin{array}{l}\text {. School psychology a possible specialization } \\
\text { within the courses leading to a master } \\
\text { degree in psychology (Bratislava). } \\
\text {. Courses on school psychology in Bratislava } \\
\text { and Presov (postgraduate - without additional } \\
\text { degree). } \\
\text {. Psychologists employed by innovative } \\
\text { schools. } \\
\text {. Intensive co-operation between SPA of the } \\
\text { CSFR and the International School } \\
\text { Psychology Association. }\end{array}$ & $\begin{array}{l}\text { Psychologists employed by innovative } \\
\text { schools. } \\
\text { Growing awareness of the school psychology } \\
\text { as a distinctive } \\
\text { applied and scientific discipline. } \\
\text {. Czech psychologists members of the School } \\
\text { Psychology Association of the CSFR. }\end{array}$ \\
\hline 1993 & \multicolumn{2}{|c|}{$\begin{array}{l}\text { Split of the Czech and Slovak Federal Republic into the Slovak Republic and the Czech } \\
\text { Republic.The SPA of the CSFR changed its name into SPA of the SR and CR but keeps both } \\
\text { the Slovak and Czech school psychologists working together. }\end{array}$} \\
\hline 1993 & \multicolumn{2}{|c|}{ XVlth International School Psychology Colloquium held in Banská Bystrica Slovakia } \\
\hline 1993 & \multicolumn{2}{|c|}{$\begin{array}{l}\text { The Slovak Parliament passes new Act } 279 / 1993 \text { recognizing school psychologist as } \\
\text { an independent and eligible to be employed by public schools. }\end{array}$} \\
\hline
\end{tabular}

Figura 3. Overview of the history of school psychology in Slovakia And the Czech Republic (continued)

I find the quality of co-operation between the teachers and school psychologists as one of the factors, which can help school psychologists to establish themselves, particularly in the countess where school psychology is a newly established or developing profession. In any case, there will be always many times more teachers than school psychologists will. While we may feel proud of having a quite unique position in schools as specialists, we should realize also that any change aimed at a higher system level in education will not happen without active support of the teachers. To achieve necessary level of cooperation we need teachers as partners who understand us. Do they? Do we have a good quality of co-operation with the teachers? Are they prepared well enough to communicate with us, to use our language? In Slovakia psychology courses are built into the teacher education. It makes, however, less than $10 \%$ of the time student teachers need to graduate from the university. No wonder that teachers have difficulties to cooperate with school psychologists. The psychological reports are written in a "foreign language" they can't understand well enough. According to their own feeling, the student teachers would accept more psychology if the universities provided it. The challenge stays than with the school psychologists involved in preparing university programs for future teachers. And it is not only the time provided for courses on psychology. In Slovakia, I dare to say, the psychology taught at the faculties of education, which prepare future teachers, remains very theoretical. It also comes rather ear1y at the beginning of teacher education not later after students have had some practice and could relate the theory with practice. 


\section{International Co-operation}

Development of school psychology in Slovakia and the Czech Republic is also a good example of the power and necessity of international co-operation within specific fields. It was active involvement of individual school psychologists in the international co-operation, which allowed holding the XVIth international School Psychology Colloquium in Bystrica in the summer of 1993. The conference was successful, received good media coverage. It was probably for the first time in history that school psychologists were given space in the main news. I am quite positive to think that the presence of the international community of school psychologists helped to create image of a serous profession and contributed to the overall development of school psychology both in Slovakia and the Czech Republic.

Ali the above mentioned factors, hard work of psychologists dedicated to school psychology, support coming from the international professional community, ISPA in particular, co-operation with the Ministry of Education of the SR, and the public activities of the Association together created the pressure resulting into the reformed School Act adopted by the Parliament of the Slovak Republic (Act $N^{\circ} 279 / 1993$ ) in the fall 1993. In this Act for the first time in history of the Slovak Republic a school psychologist was officially recognized as an independent professional providing special psychological services for schools. Furthermore, according to the new legislation schuss can employ school psychologists, not only by the Pedagogical-Psychological Guidance Centers as it was before.

- Creativity and hard work of individual psychologists

- Co-operation of the SPA of the CSFR with ISPA, CASP, NASP

- Co-operation with the Ministry of Education

- Proactive work in preparing proposals for the legislation

- Organizing XVIth ISPA Colloquium in Slovakia

- Democratie Government ACT N²79/ 1993

Figura 4. Factors which Contributed to the Official Recognition of School Psychology in Slovakia

A decree specifying the functions and roles of school psychologists in more detail carne out three years later (Decree on Educational Counseling, 1996). The framework for the work of school psychologists is quite general allowing a lot of flexibility and tailoring the psychological services to the needs of particular school. (It goes far beyond individual/group testing and it leaves relatively enough space for furthers developments for years to come).

The two above-mentioned documents provide legal basis for developing school psychology in Slovakia further. The situation in the Czech Republic is different in that there is no legislation explicitly naming school psychologists as a professional who delivers psychological services as yet. 
One of the main tasks of the Czech Section of the Association therefore is to cooperate with the Czech Ministry of Education in preparation similar legislative framework.

\section{The Current Status of School Psychology In Slovakia and the Czech Republic}

\section{Slovak Republic}

Psychology can be studied at the Faculties of Philosophy of two traditional universities: the Communes University in Bratislava, and the P.J. Safarik University in Kosice (Faculties of Philosophy). Additional opportunities were opened recently at the Universities in Bratislava, Trnava, Nitra, Banska Bystrica (Faculties of Education) where it is taught as a subject the student teachers can choose as their specialization. In these cases the graduates do not obtain title of a psychologist - they become teachers qualified to teach psychology at the secondary schools.

We do not have any precise statistics on the number of psychologists working in schools. It is estimated that about 60 work directly at the basic (grades 1 - 8) and secondary (grades 9 - 12) schools in Slovakia (there are about 30 reported in Bratislava itself). At present the Association makes efforts to gather necessary information.

The Slovak school psychologists cooperate closely with both their colleagues from the Czech Republic and also with broader international community mainly with the International School Psychology Association. The main forms of international co-operation include the following:

1.organizing common professional meeting, work groups aimed at variety of issues, e.g. preparing proposals for regulation of preparation of school psychologists, legislation related to psychological services;

2. publishing a professional journal;

3. membership and active work of the Slovak psychologists in the International School Psychology Association;

4. participation of ISP A members at our conferences, and our members at the ISPA colloquia;

5. publications of Slovak school psychologists in the newsletter World-Go-Round, School Psychology International journal;

6. publications of ISP A members in the

Slovak and Czech professional journals;

7. lecturing activities of ISPA members in Slovakia including specialized courses on school psychology offered at the Communes University in Bratislava;

8. relatively rich personal contacts internationally mediated via ISP A activities and our members' involvement.

The main issues the Slovak part of the School Psychology Association of the Czech \& Slovak Republics can include (but are not limited to) the following points:

1. clarifying distinction between the psychological services offered by school psychologists and those offered by counseling psychologists;

2. establishing minimum educational standards for school psychologists (there have been several types of courses in school psychology in Slovakia, not all graduates are recognized as fully qualified psychologists);

3. promoting better co-operation between school psychologists and teachers;

4. gathering more precise information about psychologists who have already been working as 
school psychologists in Slovakia and involve them in active work within the Association;

5. strengthening the "institution" of a school psychologist in professional community as well as in public:

6. development of an accredited postgraduate program in school psychology which would reflect standards in other countries with highly developed school psychology services;

7. development of graduate courses in school psychology corresponding to modern trends in school psychology in countries with well established traditional of school psychology;

8. developing consultant skills of school psychologists and

9. publishing professional literature and methods to be used by school psychologists working in schools.

\section{Czech Republic}

The Czech Republic carne to existence in 1993 as a result of the split of the Czech-Slovak Federation. It has a population of about 10.000.000 inhabitants, well-developed basic, secondary, and higher education.

Psychology can be studied at the Faculties of Philosophy existing at the Czech traditional universities (Charles University in Prague, Masaryk University in Brno, Palacky University in Olomouc). Quite exceptionally it can be studied at the Faculties of Education (Charles University in Prague).

Since the profession of school psychologist is not recognized by the Czech legislation there is no systematic university preparation of school psychologists as well Perhaps the program corresponding most with school psychology is the study course "Psychology and Special Pedagogic" offered by the Faculty of Education at the Charles University in Prague.

There is no independent school psychology association in the Czech Republic because there is a very well functioning common School Psychology Association of the Slovak \& the Czech Republics which was established in 1990. It has 220 members, 171 are from the Slovak Republic (78\%), and 49 from the Czech Republic (22\%), 80\% of members have psychological qualification.

Although there is no legislative background for having school psychologists in schools in the C.R., the educational practice needs a school psychologists and has pressing for establishing such function. At present about 40 to 50 psychologists work directly at the basic (grades 1 - 8) and secondary (grades 9-12) schools in the C.R. Together with the coming from the schools their initiatives pushing for changes in legislation at the top level as well.

More than three years ago an Advice Board started to work at the Ministry of Education of the C.R. dealing with problems related to educational counseling. On July 2, 1996 a seven member Work Group was established which should work out a proposal for dividing professional competencies as a school psychologist, educational counselor, and special educator should share them. Pedagogical' psycological Counseling Centers, and special educational facilities. The current President of the School Psychology Association of the Slovak and Czech Republics Dr. Jiri Mares initiated Establishment of this "task force".

The main problems of the Czech part of the School Psychology Association of the Czech \& Slovak Republics can be summarized in the following points:

1. to achieve that the profession of a school psychologist is recognized in the legislation;

2. to gather more precise information about psychologists who have already been working as school psychologists in the Czech Republic and involve them in active within our Association;

3. to resolve problem of professional competencies sharing between school psychologists and 
counseling psychologists in general as well as in individual cases;

4. to straighten the "institution" of a school psychologists in professional community as well as in public;

5. to identify a faculty which colt offer postgraduate programs in school psychology and was professionally sound enough to be accredited for that;

6. to begin with publishing professional literature and methods to be used by school psychologists working in schools and

7. to stall offering variety of specialized courses for school psychologists.

The main needs/tasks:

1 .to maintain moderate but persistent pres

sure on the Czech Ministry of Education (it is under process of changes following the elections and the old agreements may not hold) so that the function of a school psychologist is considered to be a legitimate trend in development not a bizarre effort of several devoted persons who only complicate well established stereotypes in providing psychological services to schools;

2. help in creating a basic publication on school psychology either via creating an international team of authors (which would write the whole book and this would be translated into Czech and Slovak languages) or task groups which would prepare core part on the school psychology and native authors would supplement the text with the problems specific to their country;

3. to be a mediator for the countries which have started to develop school psychology in receiving "standard" sets of methods and help them to adapt those to their own socio-cultural settings, to restandardize them;

4. to help the post-communist countries to get involved in bilateral or multilateral intentional research co-operation and

5. to establish a foundation for partial funding of the study stays of young school psychologists from the countries where school psychology has been developing only in the countries where they could rapidly grow professionally.

We believe that many problems and challenges in school psychology are common around the world. Maybe you can let us know how you approach them, how you solve them. Let us learn from each other. I believe you have many valuable findings, programs, initiatives we should know about, and we could use in developing our own ones. I hope that modern technologies will provide us better access to each other and make such closer co-operation possible.

\section{Theory and Practice - Do we respond Properly?}

In a normally functioning society a Profession can grow only in directions its services are in demand. Practice is the ultimate criterion for evaluating our thoughts. Two colleagues of mine (Kariková, Valihorová, 1997) have conducted a survey among 189 directors to find out, what kind of psychological services school directors wish to have provided $N$ any. Seventy (70) represented the so called basic schools (primary and lower secondary level), 36 secondary technical schools, 39 secondary grammar schools (so called "gymnasium"), and 38 secondary vocation schools. There were two questions - whether they would employ a school psychologist at their school, and if they would, what kind of services they would expect from a school psychologist.

163 (89\%) of the directors answered "yes" to the first question. Their responses to the second questions can be summarized in the following areas: 
- work with individual "children in need" including surveys leading to identification of these children, and work with their families;

- psychodiagnosis (connected with the selection or streaming as given by the system of education);

- consultations for the teachers regarding their work with children worth special needs;

- counseling of the parents, particularly of children with educational or behavioral problems;

- guidance for students in choosing appropriate school/educational stream;

- seminars for the teaching staff aimed on innovations and development in areas of teaching such as students evaluation and assessment, development of creativity in children;

- prevention programs (drugs, tobacco, and a1cohol in particular);

- co-operation with other institutions (pedagogical-psychological guidance centers, social workers, and variety of special education institutions );

- teaching groups of children and covering topics like health and sex education, partnership and marriage relationship;

- hot-lines for children and teachers;

- helping teachers in special classes;

- interventions with cases of aggressive behavior, bullying, and chronically maladapted students;

- involvement in creating conditions for integration of handicapped students into the mainstream and

- psychological diagnosis of teachers and training programs for the teaching staff.

We were interested how much the needs as expressed by school directors might correspond with the newest proposals for developing school psychology. We took the 10 areas as described in the most recent "Blueprint for Training and Practice II" (Yesseldyke et al., 1997) representing the developments in school psychology in the U.S.A. The comparison resulted in almost perfect match (as shown in the following picture). All but the 10th areas were mentioned in the school leaders' responses. Again, this examples proves that the practice in education has many similarities even countries so different in most aspects as a small, developing Slovakia and the USA, a highly industrialized - or better said post-industrial - country with so well developed school psychological services.

Domains of School Psychology leadership and Functions in the Schools (Yesseldyke et al., 1997)

In bold character are the domains matching the needs as identified by the school directors:

1. Data-based Decision Making and Accountability

2. Interpersonal Communications, and Consultation

3. Effective Instruction and Development of Cognitive/Academic Skills

4. Socialization and Development of Life Competencies

5. Student Diversity in Development and Learning

6. School Structure, Organization, and Climate

7. Prevention, Wellness Promotion, and Crisis Intervention

8. Home/School/Community Collaboration

9. Research and Program Evaluation

10. Legal, Ethical Practice and Professional Development

Figura 5. Correspondence Between the "Blueprint" and the Needs as Reflected by School Directors

It is very gratifying that the range of required services is so wide. It creates space for school psychology to grow. It is also a great challenge for school psychology, however. These are the 
problems that our clients perceive and this is what they look for. School psychology can reflect this needs and grow or remain bound to traditional areas and become obsolete or put aside to a slower moving train".

An example can be found in the Netherlands. The school system was changed some years ago. Schools were required to acquire more independence and self-management. The leadership was challenged by completely new tasks related to the school as organization. Inability of psychologists serving schools to offer such services pushed them out of the schools. Psychologists working in industry and other professionals specializing in organizations took over a relatively lucrative area of jobs within the educational sector. The message is clear: systems in transitions need professional help. Those who can offer it can grow, those who can not have to become satisfied with the lesser part of the cake.

\section{Preparation of School Psychologists}

Can school psychologists in Slovakia and the Czech Republic face the challenge, which comes from the schools today? Certainly not without proper preparation. The present new conception of school psychologists' training does not take into consideration the specialization in the study. It means that prospective school psychologists will study in the line of psychology for five years as any students in other specialization in psychology. On graduation students are awarded the title of the "magister" (M.A.) in psychology. It is expected that their general and basic psychological education will be developed further in variety of postgraduate courses. In practice graduates of any specialization can apply for a position where a psychologist is needed regardless of the branch they specialized for in the course of their studies.

To meet the changing needs new and greater variety of training programs must come to place. Existing university programs provide basic knowledge and a limited practical experience. Furthermore they focus mostly on diagnostic and intervention with individuals. School psychologists rarely find themselves competent enough to offer system consultations, to intervene to the system of education, teaching styles. Strengthening their skills in designing and realizing research should also be considered.

At present the overall economical and political situation is far from being optimal and favorable to education sector. In spite of that school psychology courses are planed in almost all universities in Slovakia (Bratislava - Faculty of Philosophy and the Faculty of Education, Trnava, Nitra, Kosice, Presov, and Banská Bystrica). It is a suitable time to come with programs reflecting up-to-date developments in school psychology, programs that are of comparable quality to those available in countries with long and strong traditions in school psychology. We hope that many problems related to education of school psychologists in Slovakia as well as in the Czech Republic can be better solved in co-operation with colleagues in other countries. We will use the ISPA as a means towards achieving a productive forms of cooperations. This is a big advantage we see in belonging to the ISP A. Today's world is about communications. The better we communicate, the 
more effective we become. Tank you for inviting me here to promote communication between the Brazilian school psychologists and the international professional community in this field.

\section{References}

Furman, A. e Gajdosová, E. (1991). The present state of school psychology In Czech-Slovakia. Paper at an international conference. Budapest.

Furman, A. (1997). An update on school psychology In Slovakia (Personal Files). Pedagogicka fakulta UMB, B. Bystrica.

Hu, S. e Oakland, T. (1991). Global and perspectives on testing children and youth. Na empirical Study. International Journal of Psychology, 263, s. 329-344.

Kerhervé, J. P. et al. (1997). Psychology in the educational system in Europe. (Summary of the Task Force Report). European Federation of Professional Psychologists Associations.

Keys, W. e Harris, S. Fernandes, C. (1997). Third International Mathematics and Science Study. First National Report, Part l. NFER, Slough.

Mares, J. (1 997). An update on school psychology in the Czech Republic. (Personal Communication). Lekarska fakulta UK, Hradee Kralove.

Marsh, A. J. (1991). School psychology in the European Community. Educational and Child Psychology,8. 724.

Oakland, T. e Cunningham, J. (1992). A survey of school psychology in developing countries. School Psychology International, 13.99-129.

Vyhláska M.S. (1996). Mládeze a sportu Slovenskej republiky c. 43/1996 o podrobnostiach o rychonom poradenstve a o poradenkysh zariadeniach. Devree on Counseling In Education.

Yesse1dyke, J.; Dawson, P.; Lehr, C.; Reschley, D.; Reynolds, M. e Telzrow, C. (1997). School Psychology: a blueprint for training and practice it. National Association of School Psychologists, Bethesda, MD.

Zákon NR SR c. (1993).27911993 Zb. Oskolskych zariadeniach (Act 279/1993 on educationa1 institutions). 